\title{
Mellan hästens öga och människans strävan
}

\section{En dialektisk relation gestaltad i biografiska porträtt}

Att beskriva hästar eller andra djur i porträttliknande fragment eller utsagor är en etablerad praktik och en genre som förekommer i olika sorters material och sammanhang. I hästflickslitteratur, säljannonser, diskussionstrådar på nätet eller folklore i stallmiljöer, arkivmaterial och inom levnadshistoriskt berättande beskrivs hästars personlighet, utseende, kropp, lynne och tolkningar av deras uttryck $i$ interaktion med människor och andra hästar. I ett par exempel från Nordiska museets frågelistsvar från undersökningen "Hästen" från mitten av förra seklet förekommer till exempel beteckningar av enskilda hästar som god springare, trogen, friskt humör, pissmär, krubbitare, istadiga (NM:106). I säljannonser på sajten "Hastnet. se" används beskrivningar som traderas och befästs som möjliga att karaktärisera en hästs personlighet. Förekommande ord är till exempel flott, talangfull, lugn, lättlärd, villig, pålitlig, framåt, bra lynne, vilka alla har positiva konnotationer ur en tänkbar köpares

Nyckelord: häst och människa, antropomorfism, biografiska porträtt av hästar, mellanartslig relation 
perspektiv. I diskussionstråden "Gnägg vad har din häst för personlighet" (Bukefalos, 12 november 2013) förekommer betecknande ord som lat, har en räv bakom öronen, tant, intelligent, harmonisk, tar livet med ro, vass, bufflig, problemlösare med flera. Här uttrycks också ambivalens och motstridigheter i en del av porträtten. En häst beskrivs vara klok och förståndig men samtidigt lättstressad, till skillnad från säljannonsernas mer harmoniserande och helgjutna porträtt. Möjliga sätt att beskriva hästar som unika individer och sociokulturella varelser inom det mänskliga återskapas som en mångfacetterad genre inom dessa varierande materialtyper. I dessa exempel anas en intertextuell relation inom genren, tidstypiska uttryck såväl som mer unika benämningar.

Sammantaget existerar dessa inom en sociokulturell repertoar som skapats i interaktioner med specifika hästar men som här används i kommunikation mellan människor. Beteckningarna utgör också exempel på innebörden av begreppet zooësis som är både titel och bärande perspektiv i litteraturvetaren Amelie Björcks studie om kulturella gestaltningar av lantbruksdjurens tid och liv (2019:12). Begreppet härrör från grekiskans zoion (djur) och är hämtat från teater- och performanceforskaren Una Chaudhuri. Zooësis innebär att studera de sätt djur framträder och förstås $i$ människors kultur, hur de tar plats och representeras. Speciellt relevant för denna artikel är frågorna om vilket utrymme och agens djur (i det följande hästar) kan erhålla och vidare om analysen av ett empiriskt material kan skapa nya eller alternativa sätt att förstå och reflektera över djur-människa relationens maktordning.

\section{Bakgrund, syfte och utgångspunkt}

Som egen hästhållare har jag både hört ett antal och använt egna beskrivningar och porträttliknande fragment med tolkningar av hästars personlighet. Det har till exempel handlat om vad en unik hästindivid tycker om att äta, göra eller träna på, hur hen agerar i sin hästflock, eller hur hen har ändrats i temperament och fysik över tid. Utifrån daglig interaktion och i jämförelser med andra 
hästars personligheter eller människors dito har fragment till mer helgjutna berättelser skapats. Denna vagt medvetna narrativisering har (nog) handlat om att i det dagliga varat söka förstå och interagera med en hästpartner, anpassa det egna förhållningssättet och därmed skapa ett emotionellt och fysiskt utrymme för två individer i ett vardagligt samspel. Det har också handlat om att skapa en relation mellan en häst och dess nätverk inom det mänskliga, som familj, vänner och tillfälliga gäster. Vid närmare eftertanke har porträtterandet inte utgått från enstaka tillfällen som varit lätta att erinra utan det har varit fråga om en process. Ord på karaktärsdrag har vuxit fram genom sinnliga förnimmelser som varit återkommande under längre perioder. Ord och föreställningar har också ändrats genom antalet timmar tillsammans, skiftande erfarenheter, men även genom samtal och utbyten med andra hästhållare. Efterhand har jag blivit uppmärksam och nyfiken på denna tämligen oreflekterade praktik, på de ord jag hört eller själv använt för att beskriva husdjur generellt, och hästar specifikt. Porträtterandet liknar det som utövas i en familjär gemenskap om och mellan människor. Positivt konnoterade ord öppnar upp för att skapa en relation medan negativt konnoterade kan gör det motsatta. Vad gör beteckningar av hästen med relationsutrymmet och med dess möjlighet till agens och platstagande? Dessa reflektioner har föranlett en undersökning av talet om hästar och talet om en mellanartslig relation inom det levnadshistoriska berättandet. Artikelns syfte är att söka skapa insikter i djur-människa relationen genom närläsning av porträtt och beskrivningar av sammanflätade biografier i ett intervjumaterial. Empirin består i huvudsak av två ämnesinriktade levnadshistoriska intervjuer med erfarna djurhållare för häst, samt två skriffliga porträtt av unika hästar. Frågor jag använt i bearbetning av materialet är: Hur beskriver informanterna sina hästpartners? Vad gör dessa tolkningar med relationsrummet och med en möjlig artsöverskridande interaktion? Och vilka betydelser av en mellanartslig relation uttrycks i skildringar av ett delat livslopp?

En central utgångspunkt i förståelsen av djur-människa relationen är att den är konstruktivistisk, i linje med samtida djurstudier inom humanistisk och samhällsvetenskaplig forskning (t.ex. Ekström 
\& Kaijser 2018). Relationen förhandlas och uttrycks i socialt och kulturellt förväntade former med variationer inom olika kontexter. Inom det mellanartsliga rum som skapas mellan en häst och dess människa kan relationen vara både stabil, temporär och föränderlig till sin karaktär. Relationsrummet är unikt och till sin uppbyggnad dialektiskt där två parter ömsesidigt agerar och påverkar varandra. Titelns inledning Hästens öga används som en symbolisk och reell referenspunkt som kan avslöja hästens modus och sinnesstämning som dess människa har att ta hänsyn till. Formuleringen Människans strävan avser den vardagliga praktik som uttrycks i hästhållarens sinnliga upplevelser, tankar, förhållningssätt, träning och omvårdnad.

Den följande texten är disponerad i tre avsnitt och en kortare avslutning. Nästa underkapitel inleds med en beskrivning och analys av ett empiriskt exempel på en specifik häst, följt av tidigare forskning som teoretisk inramning för artikeln. Därefter följer två empirinära avsnitt där jag prövar att beskriva och tolka innebörden av relationen mellan två kvinnor och deras hästar ur ett levnadshistoriskt perspektiv (Arvidsson 1998, Redmalm 2006:50-51).

\section{Oreflekterad, förtryckt eller alldaglig}

Det som utmärker sig med Chester för mig är först och främst hans sätt att vara en gentleman mot både andra hästar men även i relation till människor, med en inre styrka som var självklar i sitt sammanhang utan att tulla på sina gränser. Och hur hans personlighet avspeglar sig i allt egentligen, det som händer på gården på ett eller annat sätt. Det kan komma hit hästar till stallet som är stressiga, men på ett par veckor är de mycket lugnare och han på något sätt fogar in dom och gör nånting magiskt som gör att dom kommer in i sig själv på ett annat sätt. Det är på något sätt hans unika egenskap.

Chester 23 år, en specifik häst av rasen quarter som porträtteras i citatet finns inte längre i jordelivet. Han beskrevs som en idealt balanserad personlighet i sociala sammanhang vid ett samtal med 
sin tidigare hästhållare. Utdraget kommer från en intervju med informanten Asta, en så kallad fritidsryttare som tidigare har tävlat inom westerngrenar och levt med och bredvid sin häst under dryga tjugo år. I citatet uttolkas Chester som en unik individ som agerar i enlighet med en subjektiv förmåga för konkreta syften. Hästen tillskrivs ha ett autonomt agentskap med specifika egenskaper som hans människa tolkar att han uttrycker och använder i interaktion med andra individer, båda mänskliga och icke-mänskliga. Benämningen gentleman står oftast för en positivt kodad manlighet och är ett komplext begrepp som ger konnotationer till den som har stil, är artig, väluppfostrad och har förmåga att se och uppmärksamma andra personer, och då särskilt kvinnor. Under intervjun och i ett skriftligt porträtt beskrivs hästens karaktärsdrag utgå från en, för andra, förnimbar inre styrka. Denna egenskap ansågs förklara hans goda interaktion med andra hästar som ledare i flocken, med sin ägare, andra djur och övriga människor på gården. Betoningen på en inre styrka och moraliska egenskaper tillskrivs vanligtvis unika individer som anses ha ett medvetande och en själ - människor - vilket står i skarp kontrast till dominerande föreställningar om djur, de icke-mänskliga på en generell nivå i moderniteten (Redmalm 2006:3-4). Att kunna interagera och "se andra" och samtidigt behålla egna gränser och inte bli (för) självutplånande bör väl ses som ett ideal för en god individ och karaktär över huvud taget oavsett artstillhörighet. Därutöver är betoningen på hästens inre styrka också intressant i relation till de åttahundra kilo muskelmassa den yttre styrkan av en quarterhäst kan utgöra.

Beskrivningen av Chesters persona är unik och på samma gång kulturellt igenkännbart i form av ett mindre individporträtt med en familjär och inkännande underton. Det uttrycks inga ambivalenser utan orden som beskriver hästens kvaliteter stärker varandra. Erfarenheter och tolkningar av Chesters uttryck, samt hans och Astas mellanartsliga relation har utgjort en oartikulerad fond som medvetandegjorts och förmedlats i det mänskliga genom ord. Genom språket och en översättning av det sinnligt uppfattade sker inte sällan en antropomorfisering där djurs ageranden tolkas och beskrivs 
med delvis samma vokabulär som för människors (Andersson 2010a:34ff, Fudge 2007:402).

Forskning om djur ur kulturella och sociala perspektiv har under de senaste decennierna kraftigt expanderat som ett tvärvetenskapligt fält för natur-, samhällsvetenskaper och humaniora. Övergripande inriktningar som Humanimal Studies (HAS) och Critical Animal Studies (CAS) har etablerats. Representationer av djur och relationen mellan djur-människa betraktas här som sociala och kulturella konstruktioner med både stabila och återkommande kulturella uttryck, samtidigt som de är kontingenta, stadda i förändring och möjliga att omformulera och förändra. Denna artikel ligger i linje med humanimal studies där studier genomförts av representationer av djur i till exempel litteratur, film, populärkultur och museiutställningar men även av vardaglig interaktion. Djurens position, roll och betydelser för människor och samhälle i olika empiriska områden har utforskats. Interaktionen anses kunna bidra till ökad hälsa och välmående hos båda (p)arter (Håkansson et.al. 2008) men den kan vara ett uttryck för en antropocentrisk maktrelation. Våra föreställningar om djur och om relationen mellan människa och djur har varierat från något tämligen oreflekterat till något djupt problematiskt ur ett makt- och nyttjandeperspektiv. Inom det senare hävdas att människan måste bli medveten, reflektera och söka ändra sin arts position som länge utgjorts av ett fullkomligt maktoch tolkningsföreträde om det som sker i människa-djurinteraktion, och vidare i kategoriseringen av arter i till exempel husdjur, ätbara djur och vilda djur. Detta perspektiv hämtar näring från både postkolonialism, genusteorier och vithetsstudier (jfr Andersson Cederholm et.al. 2014; Björck 2019; De Mello 2012; Ekström \& Kaijser 2018; Nilsson 2018).

Om djurens plats i samhället generellt har varit tämligen oreflekterad inom humanistisk och samhällsvetenskaplig forskning fram till början av1990-talet, framstår betydelser av vardagsrelationen till våra vanligaste domesticerade djur ännu relativt lite utforskad av kulturvetenskaperna och etnologiämnet. Detta trots ämnets förankring i vardagsperspektiv, etnografiska metoder och de histo- 
riska rötterna i allmogesamhällets djurhållning. Kanske är dess alldagliga och feminint kodade praktik i en delvis familjär zon ett aber för att uppmärksamma området som ett intressant studieobjekt? Eller handlar det om att vardagslivets relationer och förankring i tyst ackumulerad kunskap är svår att studera metodologiskt? Som Jonna Bornemark och Ulla Ekström von Essen pekar på i antologin Kentaturen. Om interaktion mellan människa och häst (2010:7-8) är den tysta kunskap som utgår från samspel mellan människa och häst både komplex, outforskad men relevant att studera ur ett praktiskt kunskapsperspektiv med en kombination av tvärvetenskapliga, teoretiska och gestaltande metoder (Gustafsson 2002:90ff). Den alldeles ordinära relationen till våra vanligaste domesticerade djur för också tankarna till de praktiker och händelser som sker och utspelas som vardagliga mikrodraman och den ibland intetsägande vardagslunken som Billy Ehn och Orvar Löfgren utforskat i När ingenting särskilt händer. Nya kulturanalyser (2004). En kunskapsambition med min artikel har därför varit att pröva utforska talet om hästars persona och relationer till människan i analyser av det vardagliga på en textnära nivå. Övrig forskning som jag inspirerats av är inriktningen human animal interaction (Sanders 2003) där djur ges unika identiteter av sina människor som används både inom den interna relationen och den externa till andra människor och djur. Sanders diskuterar också praxisen hos djurägare att ge djuret egna repliker för en interaktion vilket återfinns i mitt insamlade material. David Redmalms studie Mellan människa och djur. Om det dilemmatiska möjliggörandet av husdjursrelationen (2006) har också varit en viktig inspirationskälla.

För tolkningen av det empiriska materialet har begreppsparet en dialektisk relation varit centralt för att förstå villkoren, processen och innehållet för partnerskapet som utvecklas i det mentala, emotionella och fysiska mellanrummet som skapas mellan människa och häst. Detta relationsrum befinner sig i ett spänningsfält mellan olika expertsystem och vardagsliv, mellan amatörism och profession, mellan natur och kultur, biologi och samhällsvetenskaper. Min utgångspunkt för begreppet dialektik är att det både tydliggör och betecknar den process som skapandet av ett gemensamt 
utrymme innebär. I Sokrates tidiga definition av dialektik som en väg till viktig kunskapsutveckling, utgår han från utbytet mellan lärare och elev, mellan mentor och adept. Argument stöts och blöts med motargument i utvecklandet av en delad kunskap. I det ideala fallet förändrar mötet och dialogen dem båda fast det i grunden finns en asymmetrisk maktrelation (Dahlgren 1989:6). Överfört till relationsrummet mellan häst och människa kan sägas: Två (p)arter tar plats "i förhandlingar" och söker sätt att samvara och samarbeta utifrån bådas erfarenheter, förutsättningar och temporära omständigheter. Människan har makten över tanken och ansvaret för helheten. Hästen har till stor del makt över det fysiska och ansvar för delaktigheten. För att till exempel kunna föreslå en aktivitet, "argumentera och förhandla" om interaktionens innehåll, krävs respekt från dem båda. Den mellanartsliga relationen iscensätts och görs ständigt om igen, samtidigt som den bygger på det tidigare erfarna. I vardagliga situationer vägs och förhandlas kunskap och praxis mot varandra tills det ibland/vid upprepade tillfällen/ ofta uppstår en form av syntes, här översatt till överenskommelse mellan människa och häst, vilken utgör en grund för innehåll och skapandet av en relation.

Bakom till synes vardagliga aktiviteter som att rida en tur i skogen, lasta hästen i transport, eller rykta och undersöka hästens kropp ligger många timmars utövande och erfarande av praktisk kunskap (Bornemark \& Ekström von Essen 2010:8). I berättelser om hästerfarandet i facklitteratur och intervjuer refereras både stabila och mer temporära överenskommelser inom detta mellanartsliga relationsrum. Erfarna hästmänniskor på en professionell nivå framhåller en viktig insikt om dessa överenskommelser mellan arterna. Rollfördelningen mellan häst och människa kan efterhand upplevas som relativt jämlik eller så växlar den i olika situationer (Zetterqvist Blokhuis 2010:81ff, Lindal 2018). Som tidigare framhållits i avsnittets inledning verkar det inte vara givet eller entydigt vem som efterhand inträder i rollen som lärare/mentor eller elev/adept inom ett delat livslopp, vilket även exemplifieras i de två följande empiriska avsnitten. Där beskrivs och analyseras informanternas porträtterande av unika hästindivider och deras betydelser under 
ett delat livslopp. Att tala om sitt "liv med häst" krävde reflektion och ett medvetandegörande om betydelser av vardagliga praktiker och händelser. Samtalet verkade bli ett tillfälle för informanten att pröva formulera artsmellanrummets tysta erfarande och bli varse sig själv som aktivt kunnigt och erfaret subjekt på ett nytt sätt (Andersson 2010b:108ff). Positionen hästhållare hade annars oftast rört sig om att tala om de många konkreta tingen som omgärdar interaktionen såsom foder, omvårdnad och träning. Att som hästhållare summera livet som helhet med de år som delas med en, eller flera hästar ur ett meningsskapande perspektiv syntes inte vara en etablerad narrativ genre. Det är en intressant tråd att nysta vidare i som dock inte fördjupas i denna artikel.

\section{Tildra, Krafla och Sonja. Ett välfyllt andrum}

Nervös, hästrädd och ovan började jag min resa bland islandshästar med en av de mest förlåtande av alla hästar jag ridit. Jag upptäckte snart att Tildra är en lågmäld, vänlig, ganska introvert häst. Mer känslig dock än vad som i förstone kunde gissas. Hon går med på det mesta men har mycket bestämda åsikter om det är något som hon anser är fel. Jag har lärt mig lita på henne i alla väder (...) Tildra har lärt mig så mycket och botat mig från min ridrädsla. Hon har hjälpt mig vara i nuet och njuta av tillvaron som den är. Hon har aldrig svikit mig och även om jag tycker att jag svikit henne och överlåtit alltför många medryttare under några år har hon förlåtit mig tror jag. Nu när hon är 24 år gör vi oftast det vi båda tycker bäst om. Ut i skogen över stock och sten, backe upp och backe ned.

I utdraget ur informanten Sonjas personliga reflektion, beskrivs islandsstoet Tildra 24 år som en lugn sympatisk och tillmötesgående individ med tydliga personliga gränser. Hon porträtteras med orden lågmäld, vänlig och introvert vilka tillsammans förstärker en karaktär vars sinnesstämning inte innebär större fysiska eller känslomässiga utageranden. Dock upptäckte Sonja först senare vad kombinationen av lugn och känslighet i olika former kunde innebä- 
ra. Det säger något om hur lätt det är att kategorisera individer som homogena och att beteckningen lugn ofta tolkas lika med okänslig. Citatet som hämtats ur ett skriftligt porträtt avslöjar Sonjas egen förändrade tolkning av sin häst och deras liv tillsammans. I reflektioner av sin och hästens relation över tid har hon gjort en så kallad life review med en reviderad tolkning av livet som helhet och tiden med Tildra, av den egna insatsen och rollfördelningen i relationen (Arvidsson 1998:21). Sonja uttrycker både tacksamhet och milda skuldkänslor. Det handlar om vaga känslor av svek genom att ha haft för många medryttare till hästen under en period. I reflektionen framställs Tildra som den mest trofaste av dem båda genom att ha fyllt sin del av interaktionen och samvaron i relationsrummet med råge. Tildra ges rollen som den trofasta hjälparen.

Sonja är en kvinna som nyligt pensionerats. Hon bor i en lägenhet i en stad med en hund och har två islandshästar inhyrda i ett stall ett par mil utanför. Intresset för djur fanns under barndomen men hon kunde "bli med hund" först i vuxen ålder. Hon är frånskild och har två vuxna barn. Sonja började umgås med hästar och rida på ridskola i vuxen ålder i samband med att ena barnet insjuknat i en allvarlig sjukdom. Hon sökte aktivt efter ett något att göra utanför familjezonen för egen del och fann det i umgänget med hästar och ridning. Samtidigt fanns en önskan att så småningom dela det nyvunna intresset med resten av familjen. En intensiv period i livet följde. Den varvades parallellt med barnets sjukdom och Sonjas eget utforskande av vad som kan benämnas islandshästvärlden. Denna består av ett nationellt islandshästförbund med lokala föreningar, ett stort antal professionella aktörer och amatörer i olika åldrar i hela landet. Sonja deltog i kurser, läste många böcker om hästar och ridning och var en period aktiv i en lokal islandshästförening. Som relativt orutinerad åkte hon för femton år sedan på en inköpsresa hos uppfödare i landet för att köpa en stor vallack som skulle passa henne fysiskt ansåg hon. Det "klickade inte" med någon av hästarna på de gårdar hon besökte. Mer eller mindre av en slump stötte hon på hemvägen på Tildra i ett annat stall, en häst som då nyligen importerats från Island. Efter en liten provtur i skogen där det kändes som att hon och den orutinerade hästen kunde samarbeta och fick 
bra kontakt, blev det ett hästköp. Tildra flyttade till Sonjas hemlän så snart plats för henne blivit ledig i ett lösdriftsstall.

Ett par år senare köptes stoet Krafla tillsammans med en vän. Krafla importerades direkt från Island. Den isländska hästhållningen med lösdrift för hästar i olika åldrar i stora naturbeteshagar och gångartsridning ute i terräng lockande och fascinerade Sonja under flertalet besök i landet (jfr Latimer \& Birke 2009:21). Sonja har alltid haft hästarna inackorderade i olika stall utom en kortare period på fem år då hon hyrde en egen mindre gård och senare levde som sambo på en gård med katt, hund och lantbruksdjur. Kunskap om ridning, foder och hästhållning har utvecklats efterhand genom kurser, litteratur och samtal med andra hästägare till det som beskrivs en egen linje med hästens hållbarhet i fokus. Sonja hävdar att det delade livet med Tildra och Krafla, samt ett nätverk av andra hästmänniskor och deras hästar, haft avgörande betydelse för utvecklingen av hennes liv och välmående. Många prioriteringar har gjorts. Genom åren, hävdar hon med eftertryck och skratt, har det handlat om omfattande ekonomiska utgifter för skötsel, utrustning, foder och stallplatser samt mycket nedlagd tid. Ett antal tvivel har funnits om det rimliga med livsvalet, men det positiva med hästhållandet och livsstilen har ändå övervägt. I nutid reflekterar Sonja över hur hon bättre ska ta tillvara på den återstående tiden för sig och sina åldrande ston genom att fortsätta rida i terräng och bli bättre på att planera, sätta upp mål med ridning och träning anpassat för varje häst. Innevarande fas beskrivs lite som en skördeperiod för hennes och hästarnas relationsrum. Nuet innebär en plattform där tidigare problem eller misskommunikation är utredda. Med tiden upplever Sonja att hon och hästarna lärt känna varandras intentioner och kroppsspråk väl:

Vi har med åren utvecklat en kontakt där vi rätt väl känner av vad den andra vill. Tildra är som sagt en klok och förståndig dam. Hon bär barn och ovana ryttare lugnt och fint, men bara ett tag. Jag kan märka på hennes kroppsspråk - lite bestämdare steg och skakande på huvudet - och blickar när hon tycker att 'nu får det ändå räcka' (...) Tildra är ju så att hon, hon har aldrig egentligen 
låtit någon kommit nära inpå sig. Hon har väldig integritet. Hon går med på mycket, hon är snäll och ställer upp och är artig och fin på alla sätt. Men hon har en gräns 'kom inte längre än hit' så va. (...) Tildra har alltid haft en slags distans till människan har jag upplevt. Och det säger många av mina medryttare. Ja alla säger det, man kommer inte riktigt nära henne. Hon håller på sitt.

I citatet sätter Sonja ord på två förnimmelser av hästens åsikt och vilja: "nu får det räcka" och "hit men inte längre" står för ett undvikande beteende hos hästen och bottnar i hennes tolkningar av Tildras kroppsspråk och blick (jfr talet om "evasive behavior" i Zetterqvist, Blokhuis 2010:82). Sonja använder det föreställda pratet för att beskriva hästens personlighet och gränser för deras möjliga interaktion. Tildra upplevs ha samma grundmodus präglat av klokhet och integritet sedan Sonja först lärde känna henne. I citatet används också andra människors uppfattning om Tildra som individ för att styrka den egna och ge den mer tyngd. Under den första tiden som hästhållare definierade Sonja sig som väldigt grön och oerfaren, samtidigt som hon ofta var stressad av dotterns sjukdom. Sonja uttrycker att hon upplever Tildras lite lätt distanserade förhållande till människor som en stor tillgång för att hästen inte skulle ha blivit påverkad av hennes stress och oro under den besvärliga livsperioden. Kombinationen av att vara vänlig, tillgänglig men tydligt ha egna gränser anses alltså ha gynnat både den inomartsliga relationen till andra hästar och samtidigt skyddat Tildra själv från det mänskliga och de problem som kunde ha uppstått med känslor av stress i det mellanartsliga mötet. I slutet av porträttet som Sonja skrivit adresserar hon med än tydligare emfas värdet av Tildras karaktär i relation till sitt eget livslopp med en tydlig utvärdering av deras sammanflätade liv:

Hennes lugn i de flesta situationer gör mig lugn. Hon har verkligen uppfyllt alla de förväntningar jag hade på att en häst skulle kunna läka mig och låta mig får stunder då jobbiga tankar helt försvann. Att jag efter flera års sjukskrivning kunde ta mig tillbaka till hälsa och jobb är till stor del hennes förtjänst. Hon är min pärla. 


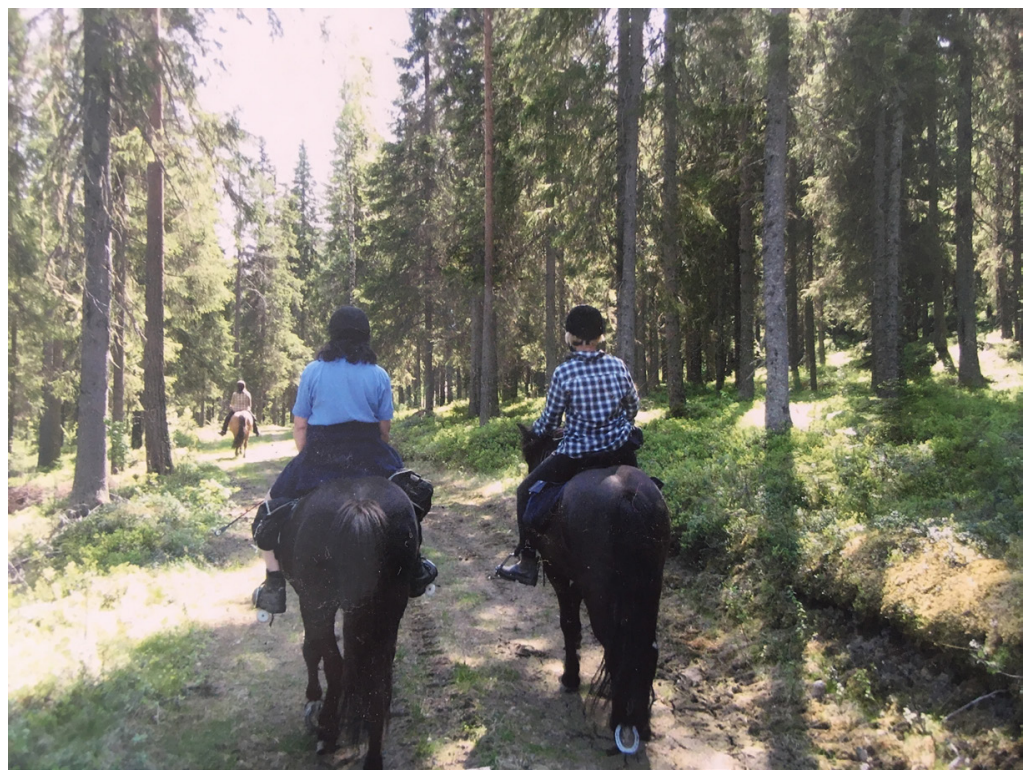

Bild 1. Sonja och Tildra tillsammans med två andra ekipage under en ridtur i skogen. Foto: Ewa Karlsson.

Under intervjun med Sonja framgår att stallmiljön och alla ridturer i terrängen med Tildra haft stor betydelse för att hantera den längre tid som präglats av ena dotterns sjukdom och den egna sjukskrivningen i samband med detta. Som relief till porträtteringen av Tildra står Sonjas berättelse om sitt andra sto Krafla. Hon hänvisar till att det är vanligt bland islandshästryttare att det "kan bli köp av en eller ett par till" efter en tid bland annat för att hästhållningen sker på lösdrift ${ }^{1}$. Tildra är en så kallad femgångshäst som förutom gångarten tölt även har passanlag. Sonja menar att hon gärna ville ha en fyrgångshäst med en rund och stark galopp vilket en del femgångshästar saknar. Hästen Krafla tillskrivs ha en helt annan karaktär. Sonja beskriver i energiska ordalag och förhöjt tonläge hur hon blev förälskad i hästen redan på den video ägaren på Island hade skickat för påseende (jfr Birke 2008:123). Hon skrattar och menar på att hon borde ha reflekterar över varför hästen fått namnet Krafla och blivit uppkallad efter en vulkan. Sonja får en speciell glöd i rösten 
när hon beskriver Krafla, hennes kastanjebruna färg, fina rörelser och mer egensinniga och temperamentsfulla karaktär.

Hon har blivit mitt hjärta. Hon har väldigt mycket egen vilja och hittar på saker och kan ju vilja bestämma sig för att inte gå fram. Hon utmanar mig på alla möjliga olika sätt. Vissa dagar rider jag inte henne för jag känner att jag inte orkar det. Men de flesta dagar gör jag det.

Sonja uttrycker att Krafla är en något öppnare, känsligare, delvis svårare men mer påhittig och karismatisk hästkaraktär som hon med åren lärt sig att samvara med och lita på alltmer. De ambivalenta och något motstridiga dragen hos Krafla kan kanske sammanfattas som en kittlande utmaning som ställer andra och kanske större krav på Sonjas egen sinnesstämning och hästerfarande i interaktionen. Den ovisshet som kan finnas i om hon och Krafla genom humörsvängningar matchar varandra varje dag, upplevs inte vara något hinder för relationens stabilitet och partnerskapet $\mathrm{i}$ ett längre perspektiv. Hon beskriver tydligt hur finstilt den kroppsliga kontakten med Krafla blivit och att hästen känner av hennes intentioner och riktning i ridningen innan Sonja hunnit göra en fysisk eller mental förhållning ${ }^{2}$.

Sammantaget framstår Sonjas porträtterande av sina båda ston Tildra och Krafla och deras egenskaper som kompletterande speglingar både av varandra och av henne själv. Egenskaper som stabilitet, lugn och trygghet i ena fallet och skönhet, lyhördhet, påhittighet och oförutsägbarhet i det andra. De både porträtten tillhör unika individer men känns igen som kategoriseringar av andra hästar och även mänskliga karaktärer i både sagor, myter, filmer och verklighetens narrativ. De hämtar näring i dikotomin mellan den lugna, trygga och säkra versus den mer spännande, fagra, men även egensinniga och utmanande karaktären. 


\section{Chester och Asta. One of two kind}

Ett annat ekipage utgörs av Chester och Asta. Hon är en kvinna i medelåldern som bor på egen gård i närheten av en större ort med sambo, katt, egen häst och två inackorderingar, två utflugna barn, tre vuxna bonusbarn. Asta har vuxit upp på ett jordbruk med närhet till olika djur och hon har ridit sedan barnsben på en mindre ridskola. Som tjugoåring köpte hon en gård och så småningom den quarterhäst som hon haft från det han var föl till de 23 år han var vid intervjutillfället.

Nu när jag haft honom sen föl, han var 6 månader då han kom. Så han har ju följt mig väldigt mycket. Både det att man har gått genom ett turbulent förhållande, till att man får barn, fostrar barn, till att man skiljs till att man också har livet som inte tar de vägar man hade trott och förhoppningar som grusas och andra vägar som öppnas. Så han har ju verkligen varit med! På en stor del av ens resa. Jag tänker så för att han är 23 och jag själv 45 år.

Som ung vuxen inriktade hon sig på westernridning som var en relativt ny gren i Sverige i början av 1990-talet. Hon tog medvetet avstånd från den så kallade engelska ridstilen, gick kurser, tränade och tävlade inom westernridning. Under tjugofem år har hon haft ett mindre inackorderingsstall och arbetat med annat utanför hemmet. Asta har varit den som inom familjen drivit på inköp av djuren (även katt och hund periodvis) och barnen har varit delaktiga på sina egna villkor. Foder har delvis tagits in själv tillsammans med brodern under semestern och delvis köpts in. Hon tänker sig en framtid med en ny gårdskatt och plats för hennes och sambons intresse för trädgård och biodling. Någon ny häst sägs inte vara aktuellt för att hon utgår från att det blir svårt att ersätta den djupa och långvariga relationen till Chester. Efter hans bortgång menar Asta att hon vill fortsätta att rida och umgås med hästar i andra stall utan att ta det fulla och livslånga ansvaret. Det kommande scenariot med dessa hästar liknas vid att åka till ett dansställe, dansa och ha trevligt, tacka, ta avsked och gå hem igen, var och en till sitt. 
Hästen Chester som refererades ovan och i ett tidigare citat tillskrivs också ha ett grundläggande modus i sin personlighet som följt honom genom livet. Asta köpte honom från en gård på Gotland när han var föl efter att ha jobbat extra med två arbeten under en period för att ha råd. Avel med quarterhästar var inte så vanligt vid denna tid och just han var dyrare än andra föl i samma ålder. Chester beskrivs genomgående som en trygg och pålitlig individ och betecknas i intervjun både som en trofast partner och en förebild utifrån sina ledaregenskaper som Asta förvånat noterade hos honom redan som föl. Han upplevdes som klok och lillgammal av både människor och hästar och intog en tydlig ledarroll i hästflockar redan som unghäst.

Ja, även som föl, han var väldigt klok och lite lillgammal om man skulle säga till en människa. Och det hade han med sig. En del av hans personlighet. Även om han var unghäst så har de andra hästarna mycket äldre än han följt honom. Och han var ledaren och bestämde. Men aldrig orättvis. (...) utan bara dom beter sig och ber snällt och uppför sig så är alla välkomna (...) Han är som en klok farbror. Även om man själv upplevt tunga perioder 'så nu andas vi in och andas ut och så går vi vidare.' Ungefär som en klok gammal farbror förmedlar det, men han förmedlar det utan ord. Visst får man den känslan att han nånstans känner av och känner med men 'man ska inte grotta ner sig för mycket utan man ska gå vidare’.

Hästen tillskrivs ha goda egenskaper såsom vis och ledare, vilka han sägs använda för att stödja Asta på ett djupare plan under krävande perioder i hennes liv. Att beskriva hästen som klok, gammal och farbror kan betraktas som ett sätt att översätta sinnesintryck av hästens uttryck och kommunikation till något igenkännbart i mänskliga termer. Flera forskare som Petra Andersson och Erica Fudge pekar på betydelsen av att betrakta uttryck för antropomorfisering mellan arterna som en resurs och medveten metod för utvecklandet av relationen. Tillskrivningen av mänskliga egenskaper skulle innebära att öka möjligheten att förstå sin häst istället för att förfrämliga den som helt skild från människan, vilket vore 
det andra alternativet (Andersson 2010a:34; Daston \& Mitman 2005:4ff; Fudge 2007:401ff). Även Redmalm är inne på samma spår i hänvisningen till sociologen Franklins diskussioner av antropomorfisering. Relationen har en potential att därigenom bli än mer symbiotisk, genom att djurhållaren tvingas erkänna och överbrygga artskillnadens olika premisser och intressen (Redmalm 2006:11). Genom att utgå från att hästen har en persona som går att beskriva med mänskliga ord, skapas en form av nyfikenhet och respekt som i sin tur kan leda till ett ökat förtroende och utbyte dem emellan.

I citatet ovan kombineras och syntetiseras Astas tolkning av Chesters personlighet med en beskrivning av det som antas vara det Chester säger till henne om han kunde uttrycka sig genom ord. Hästen har, i sin roll som vis ledare, förmedlat någon form av budskap till henne via en känsla som hon språkliggjort och formulerat med egna ord; som vikten av att andas in och ut, av att "gå vidare" med betydelsen att ej grotta

Bild 2. Asta hade bara ett fătal fotografier av Chester eller av dem båda, de många åren till trots. Denna kopia av ett inramat fotografi som stod framme på en hylla i hemmet, hade tagits under en paus på en westerntävling. (I författarens ägo.)

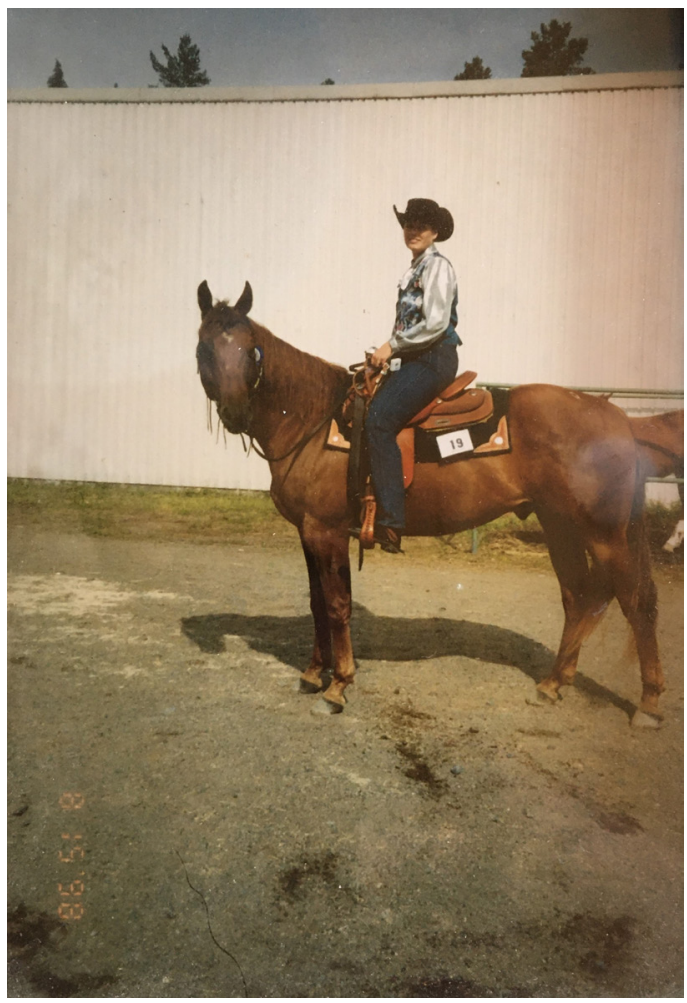


ner sig och älta för mycket genom att fastna i problem. Det rör sig om vardagliga ord och meningar med dubbla betydelser. En mer konkret och en mer symbolisk betydelse där Asta tagit fasta på den symboliska. Många krävande händelser i hennes liv parallellt med "dialogen" och varat med Chester i hästhagen uppfattades som en tröst eller hjälp. Den outtalade men ändå intuitivt uppfattade förmedlingen av en individ som levde med och bredvid henne som observatör var en återkommande aspekt som refererades i det livslånga partnerskapet med hästen. Asta säger sig fortfarande tänka på Chesters personlighet och agerande i hästflocken. Hon upplever att det fört med sig ett användbart förhållningssätt i sitt vardagliga liv och i rollen som chef med ledarskapsuppdrag för ett företag. Det senare är inte är helt ovanligt bland hästhållare (Bornemark 2010:199).

Om än han har lämnat jordelivet får han mig att tänka på hur han agerade och hur jag bör agera i mitt ledarskap både för mig själv och andra. Någon måste ta rodret men alla måste med! Att vara en förebild och hålla sin mark även när det blåser. Att tro på sig själv även om omgivningen vill annat. Men framför allt 'höj blicken och andas in och andas ut och va i nuet.' Det var hans signum.

Astas beskrivning av hästens tysta kommunikation, hennes uppfattning av ordalydelser och betydelser av densamma är intressant genom att den placerar människan i en mottagande adept-position. Hon hävdar att det inte är något magiskt eller konstigt om en kan stilla sina egna tankar och lära sig använda förmågan att "lyssna in" det djur vill tala om utan ord. I Astas porträtterande av hästen Chester och deras interaktion framstår relationen mellan dem som respektfull och jämställd. Hästens persona gestaltas som stabil och rörlig med en riktning "framåt" i alla lägen, även under prövningar av olika slag. I ett år senare inlämnat skriftligt porträtt, är hästen avliden på grund av besvär med svår tandlossning. Relationen uttrycks vara både avslutad och pågående genom minnen och förnimmelser av fortsatt närvaro. Tyngden i beskrivningen liknar de som figurerar i berättelser om nära familjemedlemmar som haft stort inflytande i livet, liksom de om släkt och goda vänner. Astas 
och Chesters gemensamma relationsrum som det refererades de sista åren, framstår som djupt och harmoniskt utan friktion, maktkamp eller övertramp. Den artsliga åtskillnaden kan kanske betecknas som underordnad och mindre viktig under den gemensamma livsprocessen. Vem som tagit initiativ, styrt eller blivit påverkad av den andre verkar ha varierat dem emellan.

\section{***}

När en hästindivid beskrivs i vardagliga samtal används ibland samma språk och vokabulär som karaktäriserar mänskliga egenskaper som beteckningen trevlig och uppmärksam eller metaforer som tant, diva, farbror, pärla, ängel eller gentleman. Dessa kan ses som ett uttryck för antropomorfa föreställningar som helt och hållet är förankrade i mänskligt språk och till det mänskliga varat i en given maktposition. I materialet blir det tydligt att porträtterandet av hästar utgått från relationen $i$ vardagen, och att narrativiseringen gjort något med planer för det gemensamma och i utvärdering av livet som levts tillsammans. Hästen blev till som aktör i det dagliga varat och inom det mellanmänskliga berättandet. Både Sonja och Asta tillskrev sina liv med häst och erfarandet stora betydelser för sitt välmående, förhållningssätt till händelser i livet och deras personliga utveckling (Redmalm 2006: 49f, Håkansson 2008:15f). Porträtten av hästarna har jag tolkat som mer stabila än temporära och tydligt förankrade i konkreta situationer och delade livslopp. Fram trädde individer med speciella grundmodus, uttalade förmågor och egenskaper som dess människa tolkat och anpassat sig till. Samtidigt uttryckte informanterna en medvetenhet om det subjektivas betydelse och risken att uppfattas ha en alltför privat eller romantiserad föreställning om sin häst. På flera ställen i intervjun flikade de in att andra människor i miljön skapat liknande uppfattningar om hästens persona, uttryck och egenskaper.

I beskrivningar av dessa hästar noterade jag informanternas ordval och kroppspåk. Inte sällan innehöll utsagor om en specifik häst eller situation en replik med en inklippt jag-subjekt-form som ett exempel på vad hästen själv skulle ha sagt om den hade fått möjlighet. 
Denna praktik av ett replikskapande med emotionell förstärkning i röst och tonläge är vanligt i både husdjursrelationen överlag och har även observerats hos personal på veterinärkliniker för att skapa mening i vårdande situationer (Sanders 2003:415-416). På samma sätt som förstärkning av relationen kan ske genom en antropomorfisering, kan dessa replikskiften också förstås och relateras till betydelser av zooësis. I det empiriska materialet finns tecken på att den artsliga skillnaden och ojämställdheten upplevdes minska genom att hästindividen så tydligt framträtt och agerat med en urskiljbar personlighet. Därigenom tolkas att hästen kunnat öka sin agens genom att inta en mental och emotionell plats i föreställda samtal och interaktion, för att återkoppla till inledningen och Björcks citering av begreppet (Björck 2019:12, 253f). Informanternas föreställningar om sina hästar har legat till grund för performativa situationer i daglig interaktion. Porträtten av Chester, Tildra och Krafla har skapats av hästhållare och speglar en narrativ praktik med intentioner inom det mänskliga. Genom berättandet artikulerades dialektiska överenskommelser, olika grader av jämvikt och betydelsen av ett mellanartsligt utbyte mellan häst och människa. Bitvis återspeglades här även en töjmån som kanske kan tolkas som en inblick i hästens egna perspektiv och erfarande, dess former av agens i relation till sina människor.

\section{Käll- och litteraturförteckning}

\section{Otryckt material}

Frågelista nr 106 "Hästen", 1947, Stockholm: Nordiska museets arkiv (Arkivet besöktes 13.11.2019).

Transkriberade intervjuer med två kvinnliga informanter (hästhållare) som genomfördes i augusti - september 2018. I författarens ägo. Två skriftliga porträtt av hästar fingerade med namnen Chester och Tildra, oktober 2019. I författarens ägo. 


\section{Webbmaterial}

"Gnägg vad har din häst för personlighet". Forumtråd i Bukefalos. 12 november 2013.

https://www.bukefalos.se/threads/vad-har-din-haest-foerpersonlighet.1207548/ (hämtad 4.12.2019).

Hästar säljes - Nordens största marknadsplats för hästar

https://hastnet.se/sv/hastar/till-salu/sida/1 (plattformen besökt vid ett flertal tillfällen 15.10.2019-15.12.2019).

\section{Tryckta källor och litteratur}

Andersson Cederholm, Erika \& Björck, Amelie \& Jennbert, Kristina \& Lönngren, Ann-Sofie (eds.) 2014. Exploring the Animal Turn. Human-Animal Relations in Science, Society and Culture. Lund: Pufendorfinstitutet.

Andersson, Petra 2010a. Du säger ingenting men du pratar hela tiden.

Kentauren. Om interaktionen mellan häst och människa. Jonna

Bornemark \& Ulla Ekström von Essen (red.). Södertörn Studies in

Practical Knowledge 4. Huddinge: Södertörns högskola.

Andersson, Petra 2010b. Vad kan en ryttare veta? Kentauren. Om interaktionen mellan häst och människa. Jonna Bornemark \& Ulla Ekström von Essen (red.). Södertörn Studies in Practical Knowledge 4. Huddinge: Södertörns högskola.

Arvidsson, Alf 1998. Livet som berättelse. Studier i levnadshistoriska intervjuer. Lund: Studentlitteratur.

Birke, Lynda 2008. Talking about Horses: Control and Freedom in the World of "Natural Horsemanship". Society and Animals 16 (2008), 107-126.

Björck, Amelie 2019. Zooësis. Om kulturella gestaltningar av lantbruksdjurens tid och liv. Göteborg: Glänta produktion. Bornemark, Jonna 2010. Ekipaget: häst och ryttare eller kentaur? Kentauren. Om interaktionen mellan häst och människa. Jonna Bornemark \& Ulla Ekström von Essen (red.). Södertörn Studies in Practical Knowledge 4. Huddinge: Södertörns högskola. Bornemark, Jonna \& Ekström von Essen, Ulla 2010. Inledning. Kentauren. Om interaktionen mellan häst och människa. Jonna 
Winroth

Bornemark \& Ulla Ekström von Essen (red.). Södertörn Studies in Practical Knowledge 4. Huddinge: Södertörns högskola.

Dahlgren, Bo 1989. Fyra teorier om utbildning. Vetenskapsteori för pedagoger. Umeå Universitet: Predagogiska institutionen.

Daston, Lorraine \& Mitman, Gregg 2005. Thinking with Animals. New Perspectives on Anthropomorfism. New York: Columbia University Press.

De Mello, Margo 2012. Animals and Society. An introduction to Human Animal Studies. London New York: Columbia University Press. Ekström, Simon \& Kaijser, Lars (red.), 2018. Djur. Berörande och kulturella smärtpunkter. Stockholm/Göteborg: Makadam.

Ehn, Billy \& Löfgren, Orvar 2007. När ingenting särskilt händer. Nya kulturanalyser. Stockholm/Stehag: Brutus Östlings bokförlag symposium.

Fudge, Erica 2007. Reviews. Can We Differ from and Live on Equal Terms with Nonhuman Animals? Society and Animals, 15, 401-408. Gustavsson, Bernt 2002. Vad är kunskap? En diskussion om praktisk och teoretisk kunskap. Stockholm: Myndigheten för skolutveckling.

Håkansson, Margareta et.al. 2008. Husdjur och folkhälsa. En forskningsöversikt om betydelsen av sällskapsdjuren och lantbrukets djur för människors hälsa. SLU och Agroväst.

Latimer Joanna \& Birke, Lynda 2009. Natural relations: horses, knowledge, technology. The Sociological Review, 57:1.

Lindal, Benny 2018 (svensk upplaga). Harmoni - Samspel. Islandshästar och ridning. Benedikt Lindal mästare i ridning. Kalmar: Leanders grafiska.

Nilsson, Bo 2018. Djurstudier, kritiska perspektiv, 'rapid ethnography' och hjältehundar. Kulturella perspektiv nr 3-4.

Redmalm, David 2006. Mellan människa och djur. Om det dilemmatiska möjliggörandet av husdjursrelationen. Mälardalens högskola: Kandidatuppsats i sociologisk socialpsykologi.

Sanders, Clinton R. 2003. Actions speak louder than words: Close relationships between Humans and Nonhuman Animals. Symbolic Interaction, vol 26, $\mathrm{nr} 3,405-426$.

Zetterqvist Blokhuis, Mari 2010. Hur fungerar samspelet mellan ryttare och häst? En forskningsöversikt. Kentauren. Om interaktionen mellan häst och människa. Jonna Bornemark \& Ulla Ekström von 
Essen (red.). Södertörn Studies in Practical Knowledge 4. Huddinge: Södertörns högskola.

\section{Noter}

1 Lösdrift är namnet för en hästhållning som går ut på att hästen vistas utomhus året om i en hage med andra hästar och kan röra sig mer fritt än i en box i stallmiljö. Ofta har de fri tillgång till vatten, salt och mineraler ibland även grovfoder som hö. Hästhållningen sägs gynna hästens naturliga beteenden och hälsa och har blivit vanligare under 2000-talet.

2 Ridterm som kort kan beskrivas som kommunikation av en riktning för ekipaget. 
Winroth

\title{
Between the horse's eye and the human endeavor. A dialectical relationship embodied in biographical portraits
}

\author{
Winroth, AnnCristin
}

Keywords: horse and human, antropomorfism, biographical portraits of horses, interspecies relationship

Describing horses or other animals in portrait-like fragments or statements is an established practice and a genre that occurs in different kinds of materials and contexts. What does the portrayal of the horse do with the interaction space and with its possibility for agency? This thinking has prompted an investigation of the discourse on horses and discussions about an intergenerational relationship within a life history story. The purpose is to seek to create insight into the animal-human relationship through a close reading of written portraits and descriptions of intertwined biographies within interview material. The article is mainly based on two subject-oriented life history interviews with experienced horse owners, as well as two written portraits of unique horses. Questions addressed in the processing of the material are: How do the informants describe their horse partners? What impact do these interpretations have on the relationship space and to a possible cross-species interaction? How is the significance of the intergenerational relationship expressed in depictions of a shared life course? A central starting point for the understanding of the animal-human relationship is that it is constructivist, in line with contemporary animal studies in humanities and social science research. In the intergenerational space created between a horse and its human, the relationship is considered unique and dialectical. It is negotiated and expressed through socially and culturally expected formats within a very specific context. The phrase The horse's eye is used in the title as a symbolic and real point of reference that reveals both the horse's mode and mood, which its human has to take into account. The words Human endeavour refer to the everyday practice that is expressed through the horse owner's sensual experiences, thoughts, attitudes, training and nursing. Stories reflecting the horse experience refer to both stable and more temporary syntheses within this intergenerational relationship space. The division of roles between horse and human can be perceived as relatively 
Mellan hästens öga och människans strävan

equal or it alternates between different situations, as exemplified in the empirical sections. 